\section{Promote Critical Thinking Through Online Discussion Forum}

\author{
Essie Childers
}

\section{ABOUT THE AUTHOR}

Essie Childers is a professor of education and integrated reading and writing at Blinn College with 31 years of classroom experience. She has served as past president of the Texas Community College Teachers Association and was recently awarded the 2017 Carol Dochen Developmental Educator of the Year Award.

re you receiving the comments and questions you desire from your discussion forums? Can you tell when students are fully engaged? Do you look forward to grading discussion forums? If you can answer a strong yes to all of the questions, then stop reading now.

The classrooms of the twenty-first century will require faculty to redefine and infuse active learning strategies to the online platform. Students are not actually learning just because they are asked to read a question and respond to two or more students. Often, students respond, "I agree with what was posted" or "Yes, I liked your post." These one-line responses are time-wasters for all readers. The discussion forum can be much more. It can serve not only as a great tool to keep students engaged and connected to the online classroom but also as a space for students to be creative and develop deep critical-thinking skills.

According to Popp (2015), through enticing students to participate in class discussions by consistently asking leading questions that extend student thinking and by contributing relevant, instructive subject-matter expertise, teachers can build a strong foundation for collaboration and engagement. Furthermore, according to Preville (2017), teaching should be less about imparting information to students and more about them developing skills while also engaging them in higher-order thinking, whether by reading or writing about the task at hand or by discussing it.

Therefore, with the words of Popp and Preville echoing in my mind, I began a personal quest to discover and develop discussion forums that were engaging and reflective and that fostered critical thinking. Have you heard of the $P M I$ instructional template? DeBono (1994) posited this structure as a very engaging discussion tool. Teachers can create a chart to utilize the $P M I$ structure with assigned readings and videos posted online to allow students to reflect on what they have read or heard. The $P$ represents what students perceive as positive comments from the article. The $M$ represents what students perceive as negative connotations or comments. The I represents what students find interesting about the article. A final step could include questions that students would like to ask the author or pose to classmates. After reading the guidelines for the discussion forum, students can download and complete the chart then post their comments. Next, students may read and comment on their classmates' posts. This instructional template can be used with videos, poems, textual readings, et cetera.

Keeping student engaged in online classes requires a great deal of effort from the instructor. However, as Barkley advocated (2010), "Teachers need to feel motivated to teach well. They need to be actively learning from their teaching" (p. 74). When using the $\mathrm{PMI}$ instructional template, I am excited to grade and comment on students' posts to see if they are really diving deep to exhibit the higher-order thinking skills of Bloom's Taxonomy (Bloom, 1956). I am intrigued to see student questions posed to the author. I can truly tell that my students are engaged and that their neurons are firing together to create other neural networks. I am motivated to continue my quest of developing more active online discussions- not only to keep me engaged in my teaching but, more importantly, to keep my students engaged in learning.

\section{... teaching should be less about imparting information to students and more about them developing skills...}




\section{References}

Barkley, E. F. (2010). Student engagement techniques: A handbook for college faculty. San Francisco, CA: Jossey-Bass.

Bloom, B. S. (1956). Taxonomy of educational objectives: The classification of educational goals, Handbook I: Cognitive domain. New York, NY: David McKay.

DeBono, E. (1994). DeBono's thinking course, $3^{\text {rd }}$ edition, revised. New York, NY: Facts on File.

Popp, B. (2015, October 8). 10 things all great online educators do. eschool News. Retrieved from https://www.eschoolnews.com/2015/10/08/ online-educators-585/

Preville, P. (2017). The active learning handbook: Engagement techniques that work. Retrieved from https://tophat.com/wp-content/uploads/ 2017/05/Active-Learning-ebook.pdf 